\title{
Multi Feature Grain Repository Structure with Security
}

\author{
Ranjitha. ${ }^{1}$, ShivaPrasada.K.H ${ }^{2}$, Dayanand Lal.N ${ }^{3}$, Asha.G ${ }^{4}$ \\ ${ }^{1-4}$ Department of CSE, GITAM School of Technology Bengaluru, India, \\ 1'rvenkate@gitam.edu, ${ }^{2}$ sgowda@ gitam.edu, ${ }^{3}$ dnarayan@ gitam.edu, ${ }^{4}$ agujjara@ gitam.edu
}

\begin{abstract}
India is comparatively the second largest country in population, food grains are the main requirement for all and hence about 50 percent of the population is involved in farming. About 40 percent of food grains are wasted in post-harvest because of traditional storage systems and other external factors that influence food grains for spoilage, according to the UNDF (United Nations Development federation). Farmers make use of traditional storage systems like Earthbins, pots, silos etc. where most of the food grains are wasted by the insects and other external commodities like temperature, humidity, $\mathrm{CO} 2$ levels are the various factors that influence the quality of grains but this wastage is to be avoided by making use of modern grain repository structure. Modern Grain repository structure is feasible for grain storage and to the maximum it avoids the wastage and spoilage of the food grains by making use of various sensors like DHT11, MQ5, and MQ135 which is majorly IOT sensors for monitoring grains quality. The modern multi-feature grain structure comes with various features that help in avoiding insects, rodents, molds and even secure enough from thefts by thieves. So this paper contributes towards the prevention of grain wastage and safety of grains which helps the farmer for his benefits. Notifying the farmer can be done using an application called cayenne and it periodically updates the farmers regarding the crop levels and any other suspicious activities. According to experimental results, this modern repository system requires very little human intervention.
\end{abstract}

Key words: DHT11, MQ5, MQ135, Cayenne, Grains Quality.

\section{INTRODUCTION}

Cultivation is the main occupation for the people since the entire world depends on the food grains either directly or indirectly even the economy of the country depends on agriculture where indirectly depends on the wastage of food which influences the economy hence there is need to avoid wastage. The issues that occur in traditional storage systems are maintaining the temperature, $\mathrm{CO} 2$ levels and other factors that influence grain quality. According to the research, the temperature between 25 and 30 degrees is very supportive for mold growth in the storage repositories and with respect to insect reproduction the temperature which is sufficient is 15 degrees Celsius and above so the grains should be stored in 30 to 40 Fahrenheit depending even on the aeration of bins is also important. There is a scenario to explain this condition very well considering a farmer who has cultivated food grains and stored them in a bin which is a traditional repository. Farmers need to check the bin three times a day, but few farmers won't even check it for months, preferably in the top portion, which should be checked at least week wise. If Farmer notices any smell or rise in the temperature due to damaged grains or wet grains or premature grains present in the bin and that portion of grains should be removed from the bin or else the entire bin will be wasted. Rise in temperature even because of high metabolic activity of insects. Farmer activities vary according to seasons that are in summer, checking bins multiple times in winter, checking it for less time, etc. several gases are released from the metabolic activity of insects like mycotoxins which naturally in foods, feeds and our environment. Mycotoxins are classified as hepatotoxins, nephrotoxins, vomitoxin and neuro-musculotoxin, some of which are potentially carcinogenic and mutagenic. [1] This mycotoxin is the reason for $\mathrm{CO} 2$ levels production in the bins and even in rise in temperature.

\section{LITERATURE SURVEY}

Authors Adesina Jacobs Moboladea, Nameirakpam Bunindro, Dinabandhu Sahoo, Yallappa Rajashekar, as given idea of traditional repository system and how the system works, to what level the grains wastage occurs etc. below is the table to describe about the traditional storage system used in those days [2] . Figure 1 depicts the procedure cleaning grains manually and Table 1 shows the various traditional practices that are implemented to store the grains.

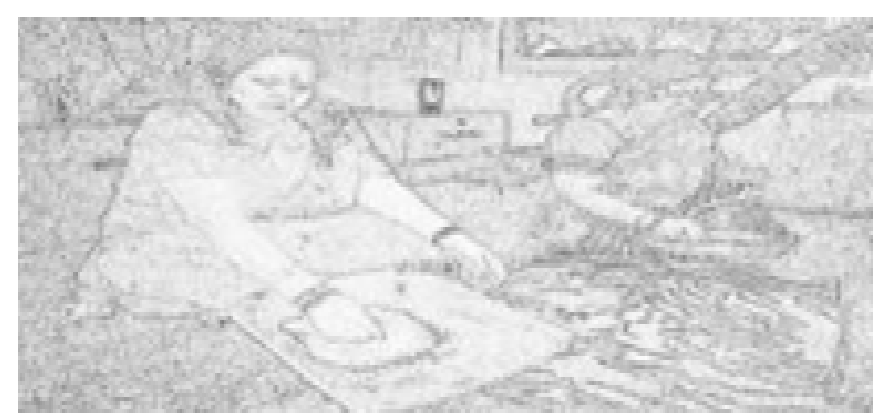

Figure 1: Before storing food grains need to be cleaned for impurities(Source: Ranjitha V) 
Table 1: Traditional Practices and storage systems

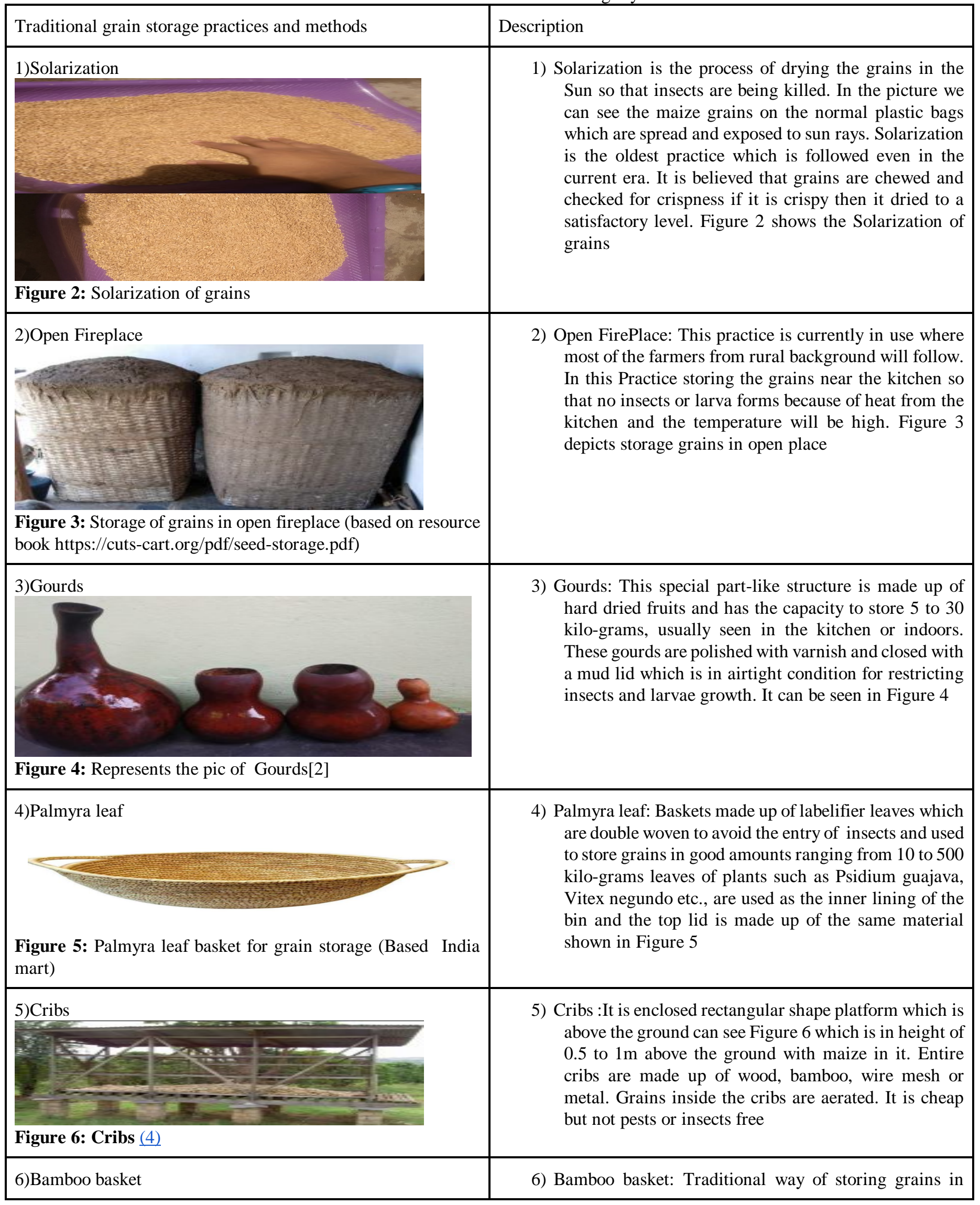




\begin{tabular}{|c|c|}
\hline $\begin{array}{l}\text { Figure 7:Bamboo basket(source:Traditional ways of Storing } \\
\text { Grains, by Muriel Kakani, 2015) }\end{array}$ & $\begin{array}{l}\text { bamboo basket which is shown in the Figure 7, bamboo } \\
\text { basket is made up of bamboo splits, straw, opening at } \\
\text { the top for filling grains in it. The exterior can be } \\
\text { varnished with mud or cow dung which is kept in the } \\
\text { open space. Storage capacity may vary based on the } \\
\text { size of the basket }\end{array}$ \\
\hline $\begin{array}{l}\text { Figure 8: Earthen pots( based on resource book } \\
\text { https://cuts-cart.org/pdf/seed-storage.pdf }\end{array}$ & $\begin{array}{l}\text { 7) Earthen pots: Earthen pots may vary in size and can } \\
\text { store grains from } 0 \text { to } 25 \mathrm{kilo-grams} \text { depending on size. } \\
\text { This structure is made up of clay. Figure } 8 \text { depicts } \\
\text { earthen pots stored one above the other perfectly } \\
\text { without any air gaps so that no insects can go in, and } \\
\text { the top pot is closed with a clay lid. This is one of the } \\
\text { oldest practices even though it is now also on the move, }\end{array}$ \\
\hline $\begin{array}{l}\text { 8)Underground pit } \\
\text { Figure } 9 \text { :Underground pit(based on [2]) }\end{array}$ & $\begin{array}{l}\text { 8) Underground pit: Farmers use this storage very } \\
\text { frequently in lands where water levels are low and this } \\
\text { can be in the shape of a bell where more grains can be } \\
\text { stored. This structure is disadvantageous because of the } \\
\text { rise in moisture content there may be possibilities of } \\
\text { mold. Storage capacity depends on size. Figure } 9 \text { shows } \\
\text { underground pit with bamboo inside fitting }\end{array}$ \\
\hline $\begin{array}{l}\text { 9) Mud house } \\
\text { Figure 10:Mud house(mercycorps.org Nepal, Re-enforcement } \\
\text { of Mud Grain Storage and Mud Houses, 2010) }\end{array}$ & $\begin{array}{l}\text { 9) Mud house: this structure can store up to } 1000 \text { to } 2500 \\
\mathrm{~kg} \text { and is made up of mud alone or can be mixed with } \\
\text { cow dung for building walls and can be covered with } \\
\text { bamboo sticks and palm leaves on the roof. Figure } 10 \\
\text { shows the mud house for storing the grains in it. }\end{array}$ \\
\hline $\begin{array}{l}\text { 10)Seeds are stored with cow dung } \\
\text { Figure 11: Seeds stored with cow dung(based on by } \\
\text { saurabhlevin,2011) }\end{array}$ & $\begin{array}{l}\text { 10) Seeds are stored even with cow dung to preserve the } \\
\text { seeds for the next seasonal sowing and it acts as one of } \\
\text { the best pesticides to prevent it from insects Figure } 11 \\
\text { shows seed in the cow pat. }\end{array}$ \\
\hline $\begin{array}{l}\text { 11)Thatch silo } \\
\text { Figure 12: Thatchsilo } \\
\text { (source:http://home.alphalink.com.au/ taraka/e14.html) }\end{array}$ & $\begin{array}{l}\text { 11) Thatch silo: This is basically in the cylindrical form } \\
\text { and made up of stones, leaf sticks etc. and the top is } \\
\text { covered with various leaves. It is } 2 \mathrm{~m} \text { high from the } \\
\text { ground. It has a capacity of more than } 2000 \text { kilo-grams } \\
\text { and it is } 2 \mathrm{mtrs} \text { above the ground level. Figure } 12 \\
\text { depicts the thatch silo }\end{array}$ \\
\hline 12)Plastic container & $\begin{array}{l}\text { 12) Plastic container: Figure } 13 \text { shows the grains in the } \\
\text { plastic container which is commonly used nowadays in } \\
\text { rural areas. It basically avoids rodent entry and is } \\
\text { covered with a plastic lid. } \\
\text { Capacity depends on the size of the container. }\end{array}$ \\
\hline Figure 13: Plastic container & \\
\hline
\end{tabular}




\begin{tabular}{|c|c|}
\hline 13)Metal silo & $\begin{array}{l}\text { 13) Metal silo: Figure } 14 \text { shows how metal silo looks and it } \\
\text { is basically made up of a metal called iron which is } \\
\text { used to store cereals and other grains for longer } \\
\text { duration. They are the best containers for grains but } \\
\text { should be placed in shady areas because of } \\
\text { condensation problems }\end{array}$ \\
\hline 14)Mud silo & $\begin{array}{l}\text { 14) Mud silo: As shown in the Figure } 15 \text { Mud silo is of } \\
\text { Spherical shape and can be seen above four or more } \\
\text { stones. It is for a shorter duration and it is closed with } \\
\text { leaves. }\end{array}$ \\
\hline 15)Plastic silo & $\begin{array}{l}\text { 15) Plastic silo: It is basically made up of PVC which is like } \\
\text { a container basically used for water but nowadays such } \\
\text { structure is used even for storing grains. Figure } 16 \\
\text { shows }\end{array}$ \\
\hline Figure 16: plastic silo(4) & \\
\hline
\end{tabular}

There are even various insects and other external calamities that affect the grains quality; few among them are considered in this paper. Storage insects have various categories, few main among them are 1) Primary storage pests under these two sub categories are presents

a) External: insects feed on germs and endosperms from the outside. Whole seeds get damaged and especially the germinal portion or feed on the seeds, which initially have been damaged by other insects which are broken into pieces mechanically. b)Internal insect pests: laying eggs on the surface or inside the grains, entire life stages of the insect from egg to last stage or part of life stage is spent inside the grains. The loss of germination cannot be identified from the outside. [5][6]

\section{2) Secondary storage pest [6].}

1) Primary Storage pest: Insects that occur in grains for the first time that is in initial times

2) Secondary storage pest: occurs on the grains which are already damaged

1) Primary storage pests

a) Rice weevil: Found worldwide which belongs to internal feeders it appears on grains like wheat, rice, sorghum, maize, barley. Rice weevil can be seen in Figure 17.

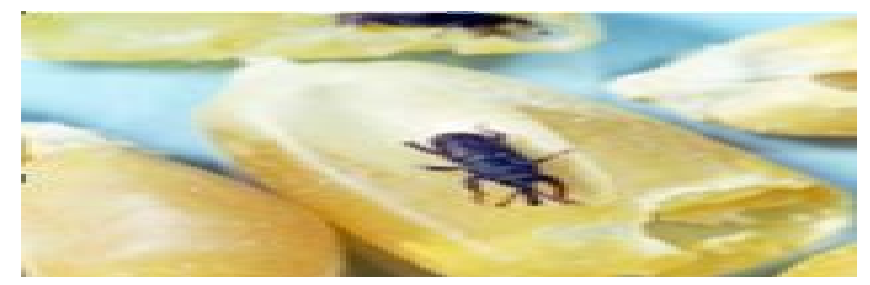

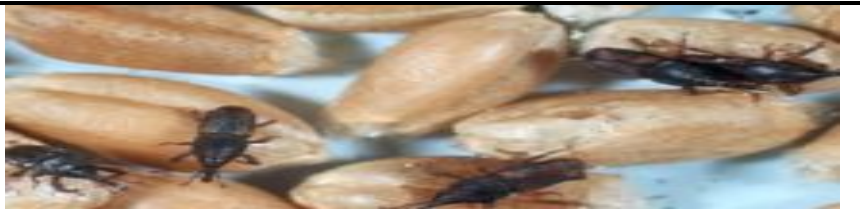

Figure 17: Rice weevil Adult (based on [5-6])

b) Lesser grain borer: Found in few places like India, Greece, US, Japan, Nepal etc. seen in foods and grains like wheat, rice, maize, sorghum, barley, lentils, army biscuits, ship biscuits, stored, corn flour, beans, pumpkin seeds, tamarind seeds and millets. This is an internal feeder. Lesser grain borer shown in Figure 18.
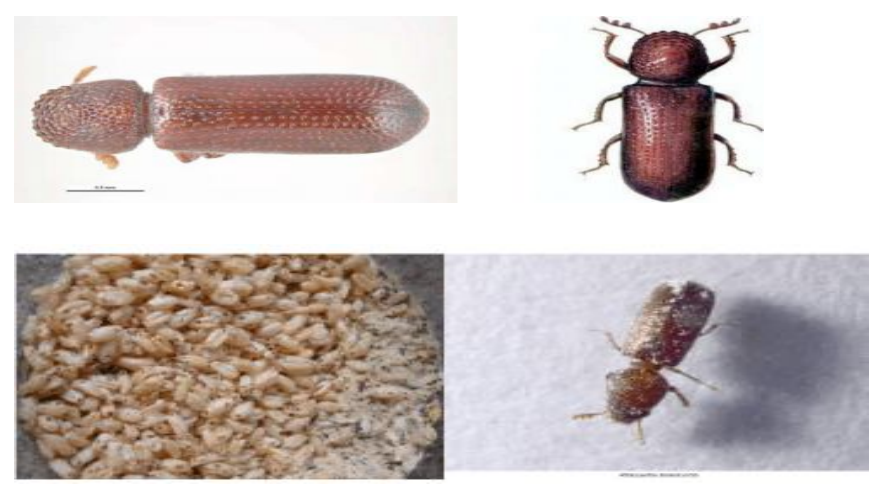

Figure 18: Powdery substance revealing damage occurred by lesser grain borer (left) and adult beetle (right) [5, 6]

b) Angoumois grain moth: Found worldwide and seen in grains like paddy wheat oats maize etc. breeding takes place in the month of April to October. This is an internal feeder. Figure 19 shows Angoumois grain moth with its stages. 


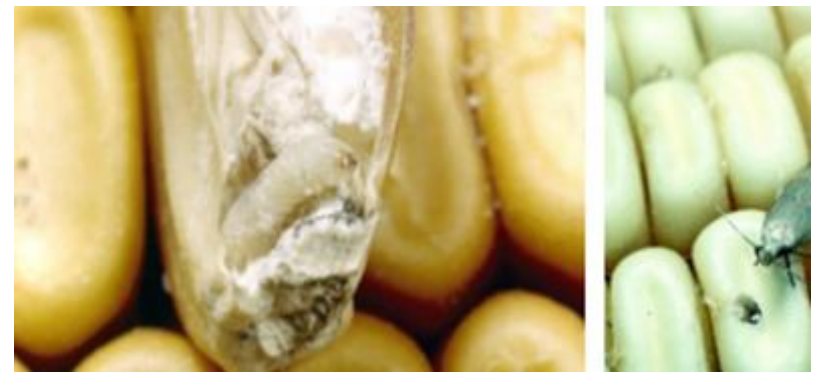

Figure 19: Angoumois grain moth with its stages [5]

d) Red flour beetle: Found worldwide, and this is an external category feeder where it concentrates on endosperm of grain. This insect is found on grains like wheat flour, dry fruits, pulses etc. Figure 20 shows Depicts the stages of Red flour beetle [5]

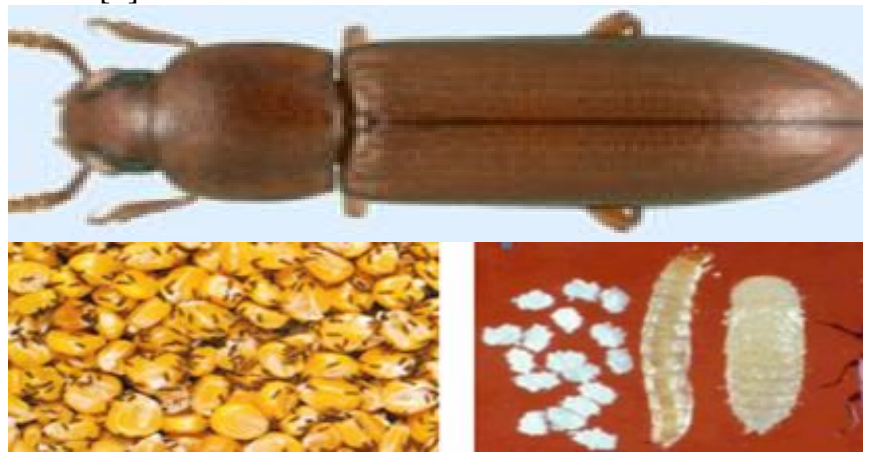

Figure 20: Depicts the stages of Red flour beetle [5]

e) Indian meal moth: Found worldwide and again this is an external category feeder which is seen in breakfast food, meals, dry fruits, nuts etc. Figure 21 shows Indian meal moth stages from egg.
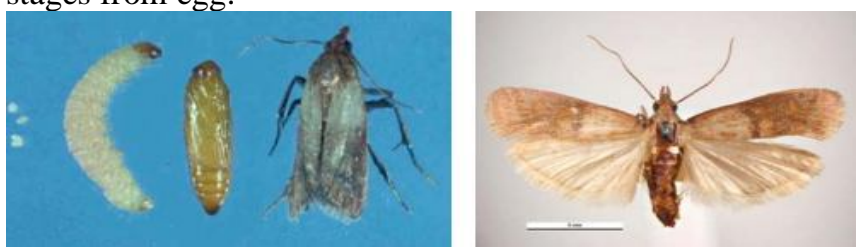

Figure 21: Indian meal moth stages from egg [5]

f) Rice moth: Found majorly in Asia, Africa, and Europe this is an external feeder, it is seen in rice maize, groundnut etc.

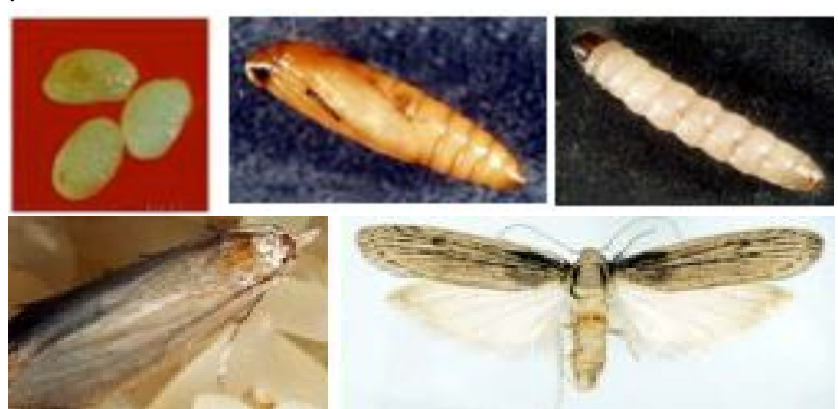

Figure 22: Rice moth eggs and larvae [5]

2) Secondary storage pest

a) Saw toothed grain beetle: It is dark in color which is found in any damaged grains like rice, wheat, maize, cereals etc. shown in the Figure 23 shows it
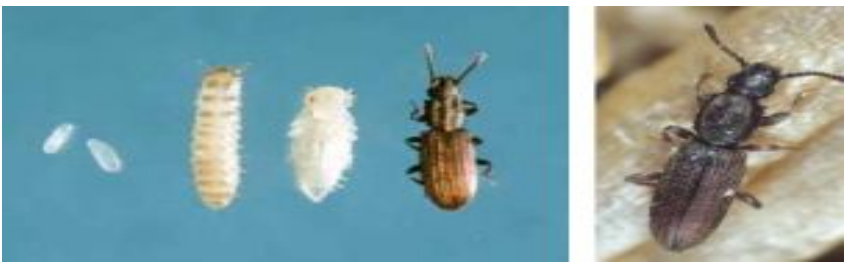

Figure 23: Saw toothed grain beetle [5]

b) Long headed flour beetle: It attacks cereals flour packaged food etc. it is a secondary feeder shown in Figure 24.
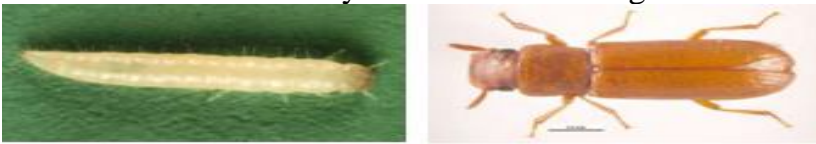

Figure 24: Shows long headed flour beetle [5]

c) Grain lice: as seen in the starchy material, it lays 7 to 59 eggs approximately. It comes under a secondary feeder, shown in 25 .

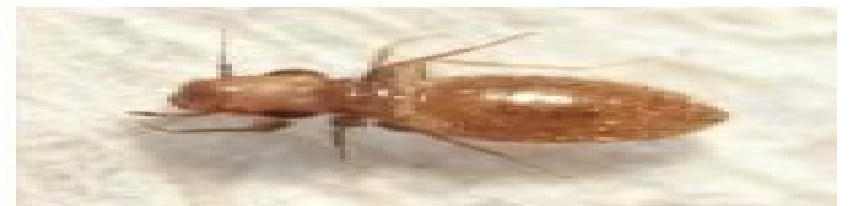

Figure 25: shows Grain lice [5]

All this are pest insects that can be seen in the storage of food grains to avoid this, we are with a new modern storage structure where the main objective is maintaining the quality of grains. There are ample of papers related to the grain storage monitoring system which is with some gap areas like it may be with respect to controlling the carbon dioxide levels or it may with reaching the farmer are triggering the events, few among such related work is to reduce grain loss by making use electronic and information technology[7][3]. By making use of Arduino microcontroller, temperature and humidity sensors, and a GSM module, an automated warehouse is created successfully by[8], a same type structure for grain storage is given by [9].Automation warehouse is enhanced with Wi-Fi model given by[10]. Similarly, monitoring the $\mathrm{CO} 2$ level of the stored grain and applying a machine learning algorithm was done for data analysis, obtained from the sensors -installed in the storage bin [11]. Applying Wireless Sensor Network (WSN) technology with bee radio transceivers inside the bin was successfully done by [12]. Rodents are one of the major factors responsible for stored grain losses [13], with respect to sub regions; an automatic grain monitoring system is given by [14]

\section{METHODOLOGY}

The modern grain repository structure makes use of a few hardware components to monitor the food grains inside the structure; mainly we make use of a few iot sensors. The proposed system is cost effective for farmers and mainly focuses on grain safety. Hardware components like

1) Microcontroller: Node MCU ESP8266

2) Sensors are MQ135, MQ5, DHT11 and PIR sensor

3) Electronic alarm, Fan, is used which will be notifying the farmer

The architecture looks like it is shown in the Figure 26 that 
depicts the model parts and its way of communication with the farmer.

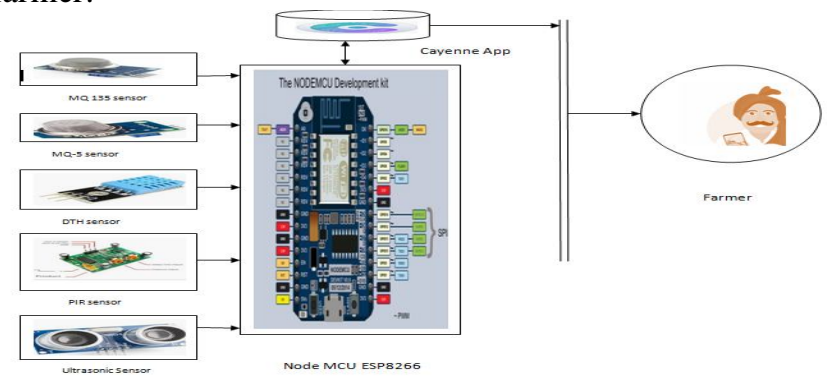

Figure 26: Architecture of the model

1)The Node MCU (Node Microcontroller Unit): A firmware which is of open source type with interaction, from Espressif systems and the hardware is of type ESP_12 with Wi-Fi module supports various components, WSN that is for monitoring the surroundings and even TCP/IP protocol [15][16][17].For selecting Node MCU, there are various research studies which say NodeMCU is stable and a successful few among them are: detecting the fire in the forest[18], Robot controlled by Wi-Fi[19], Power transformer monitoring system[20], Tomato sorting machine[21], air quality control based on automated system[22], automated electricity billing system[23], Body temperature and heart rate detecting system[24], LPG gas leakage detection and alert System[25].

2)Sensors are MQ135, MQ5,DHT11,Ultrasonic and PIR sensor: The Sensors like MQ135 and DHT11 selected for the security grain system which successful in detecting $\mathrm{CO} 2$ levels with respect humidity [27], Passive Infrared sensor (PIR) can identify easily.[26]PIR was successful in detection given by [30][31][32][33][34] . MQ5 is successful in detecting the natural gases [28]. Ultrasonic sensors are used to detect levels of grain in the repository structure, and are successfully given by. [36][37][41]

3)Electronic alarm, Fan, is used which will be notifying the farmer: In order to notify the farmer regarding abnormal state of repository structure we are using an electronic alarm and also fan to regulate the temperature and also the entire module is set as a relay module. Running Time Alarms Monitoring is given by [39]

Software required for this application are Cayenne Application: Application is required to alert the farmer and this is success in [29] [38]. Arduino IDE: By making use of embedded $\mathrm{C}$ language code is developed and can be dumped into micro controller. [35]
Data Flow Analysis

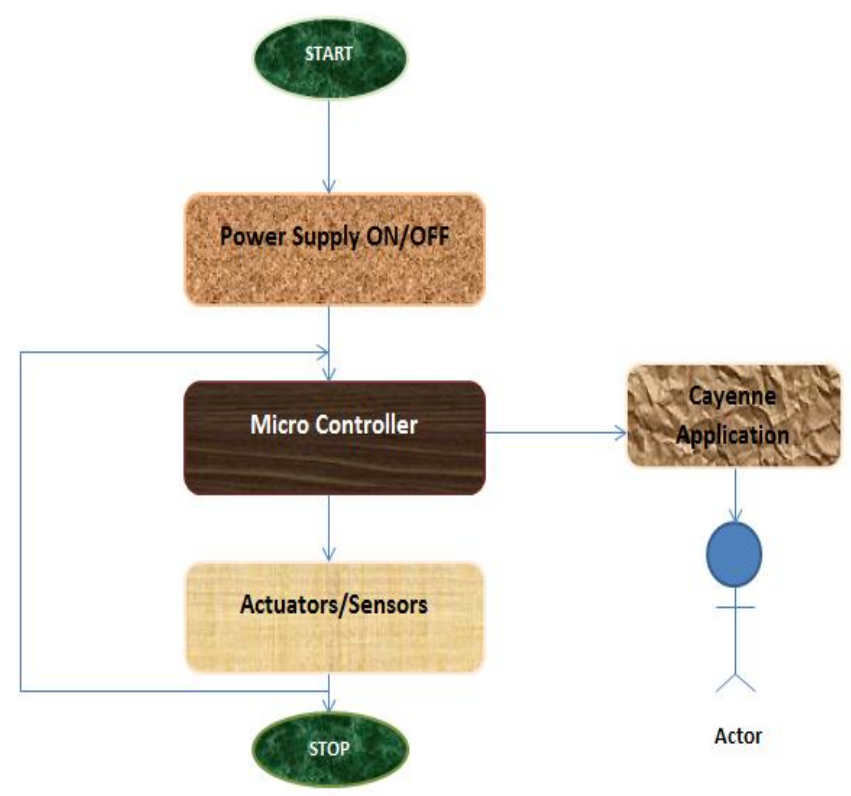

Figure 27: Data flow analysis

Data flow analysis shown in the Figure 27 where it depicts the complete flow of repository structure where microcontroller is dumped with code operates with power supply and with the help of cayenne application the actor is notified by sensors or actuators readings so that the abnormal state is controlled, here abnormal state is like variation in the temperature, movements of rodents, mold growth etc. Even insects can be avoided by making use of a few procedures inside the repository like sanitization of the repository structure when it is empty.[40]

\section{RESULT ANALYSIS}

Complete readings of sensors are detected simultaneously and with respect to variation in the state of Repository structure electric alarm and notifications are sent through cayenne application to farmers, the sensors that we are using are meant for various applications like MQ135 for atmospheric gases, MQ5 for LPG gas and other smoke, PIR sensors for detecting rodents and other warm grainy cells. Table 2 shows the results. 
Ranjitha.V et al., International Journal of Emerging Trends in Engineering Research, 8(8), August 2020, 4588 - 4595

Table 2: Results

\begin{tabular}{|c|c|c|}
\hline Attempt number & Results & Status \\
\hline $\begin{array}{l}\text { Attempt 1: By } \\
\text { varying } \\
\text { Temperature in the } \\
\text { repository structure }\end{array}$ & Detected & Success \\
\hline $\begin{array}{l}\text { Attempt 2: By } \\
\text { inserting insects in } \\
\text { the grains and } \\
\text { storing wet seeds in } \\
\text { the repository }\end{array}$ & $\begin{array}{l}\text { Detected } \\
: \quad \text { with } \\
\text { insect } \\
\text { and mold } \\
\text { growth } \\
\text { initializa } \\
\text { tion and } \\
\text { notified } \\
\text { the } \\
\text { farmer }\end{array}$ & Success \\
\hline $\begin{array}{l}\text { Attempt 3: By } \\
\text { reducing the levels of } \\
\text { grain in the structure }\end{array}$ & $\begin{array}{l}\text { Detected } \\
\text { and } \\
\text { Notified }\end{array}$ & Success \\
\hline $\begin{array}{l}\text { Attempt 4: By } \\
\text { varying the humidity } \\
\text { levels }\end{array}$ & Detected & Success \\
\hline $\begin{array}{l}\text { Attempt 5:Others } \\
\text { abnormal activities } \\
\text { like } \mathrm{CO} 2 \text { gas in the } \\
\text { repository }\end{array}$ & Detected & Success \\
\hline
\end{tabular}

\section{CONCLUSION}

Since, large amounts of grains are wasted every year because of lack of maintenance and even a traditional way of storage (seen in section 3) also leads to poor quality crops, hence the attempt is made to assist the farmers from various parameters like temperature variation because of various insects (mentioned in section 3) that releases different gases due to metabolic activity, which affects the crops and other rodents etc. In this paper, maintaining the quality of grains is achieved, where this Multi features grain repository structure uses NodeMCU and other sensors. Readings of sensors are displayed on the mobile of the farmer where the entire control of the structure will be in farmer's hands, since temperature, carbon dioxide and humidity levels are all continuously monitored by the model, simultaneously notifying the farmer. The output can be seen on mobile and desktop. Future enhancement is for increasing the monitoring activity for large structures with less cost for farmers and avoiding wastage of crops.

\section{References}

1. Maitree Suttajit, Ph.D. "Prevention and control of mycotoxins" http://www.fao.org/3/x5036e/x5036e0q.html
2. Adesina Jacobs Moboladea, Nameirakpam Bunindro, Dinabandhu Sahoo, Yallappa Rajashekar, "Traditional methods of food grains preservation and storage in Nigeria and India",2019

3. Sahana, D.S., Dayanand Lal, N., Neetha, K.S., Nida Kousar, G., Sakkari, D.S., "Software defined network evolution: A quality viewpoint for enterprise management", International Journal of Advanced Trends in Computer Science and Engineering, 2020, volume. 8, Number 7 of IJETER

4. Charles Owach, Godfrey Bahiigwa, Gabriel Elepu,"Factors influencing the use of food storage structures by agrarian communities in Northern Uganda “,2016

5. Lecture 32, "Stored grain pest" by eagri.org http://eagri.org/eagri50/ENTO331/lecture32/lec032.pdf

6. Srivastava, Chitra 0 Sabtharishi, Subramanian. (2016). "Storage insect pests and their damage symptoms: an overview". Indian Journal of $\quad 78$. 10.5958/0974-8172.2016.00025.0.

7. C. B. Singh and J. M. Fielke, "Recent Developments in Stored Grain Sensors, Monitoring and Management Technology," IEEE Instrumentation \& Measurement Magazine, pp. 32-55, June 2017.

8. J. S. Shilpa and G. M. Sheeba, "Automated Real Time Monitoring for Food Grain Storage," International Journal of Pure and Applied Mathematics, vol. 118 No. 24 , pp. 1314-3395 , 2018.

9. A. Bazhenov, N. Grivennaya, S. Malygin and A. Knyaginin, "Distributed System of Remote Control and Management of Technological Processes of Granary," in 17th International Scientific Conference Engineering for Rural Development, 2018.

10. A. Akila and P. Shalini, "Food grain storage management system," International Journal of Engineering \& Technology , vol. 7(2.31), pp. 170-173, 2018.

11. R. Kaushik and J. Singhai, "An Approach for the Development of a Sensing System to Monitor Contamination in Stored Grain," in the 6th International Conference on Signal Processing and Integrated Networks (SPIN), Noida, 2019.

12. M. O. Onibonoje, N. I. Nwulu and P. N. Bokoro, "A wireless sensor network system for monitoring environmental factors affecting bulk grains storability," Food Process Engineering, vol. e13256, pp. 1-13, 2019.

13. A. Manandhar, P. Milindi and A. Shah, "An Overview of the Post-Harvest Grain Storage Practices of Smallholder Farmers in Developing Countries," Agriculture, Vols. 8(4), 57, 2018

14. Tedla, T.B., Bovas, J.J.L., Berhane, Y., Davidkin, M.N. and James, P.S. 2019. Automated granary monitoring and controlling system suitable for the sub-saharan region, International journal of scientific \& technology research, Vol. 8(12):1943- 1951.

15. L. Shkurti, X. Bajrami, E. Canhasi, B. Limani and S. a. H. A. Karabaj, "Development of Ambient Environmental Monitoring System ThroughWireless Sensor Network (WSN) Using NodeMCU and -WSN Monitoring\|," in 6th Mediterranean Conference on Embedded Computing (MECO), Bar, 2017.

16. X. Bajrami and I. Murturi, "An efficient approach to monitoring environmental conditions using a wireless sensor network and 
Ranjitha.V et al., International Journal of Emerging Trends in Engineering Research, 8(8), August 2020, 4588 - 4595

NodeMCU," Elektrotechnik \& Informationstechnik , vol. 135, no. 3, p. 294-301, 2018.

17. A. Gupta, H. P. Gupta, P. Kumari, R. Mishra and S. a. D. Saraswat, "A Real-time Precision Agriculture Monitoring System using Mobile Sink in WSNs," in IEEE International Conference on Advanced Networks and Telecommunications Systems (ANTS), Indore, 2018

18. M. Basu, R. Karthik, J. Mahitha and V. L. Reddy, " IoT based forest fire detection system," International Journal of Engineering \& Technology, vol. 7 (2.7), pp. 124-126, 2018.

19. K. Mistri, "WiFi Control Robot Using Node MCU," International Journal of Engineering Development and Research, vol. 6(2), pp. 325- 328, 2018.

20. A. Mohamad, Y. Mezaal and S. Abdulkareem, " Computerized Power Transformer Monitoring based on Internet of Things," International Journal of Engineering \& Technology, vol. 7 (4), pp. 2773-2778, 2018.

21. A.A. Istiadi, S. Sulistiyanti and H. a. H. Fitriawan., "Model Design of Tomato Sorting Machine Based on Artificial Neural Network Method Using Node MCU Version 1.0,," Journal of Physics: Conference Series, pp. 1-7, 2018. https://doi.org/10.1088/1742-6596/1376/1/012026

22. D. Aziz, "Web Server Based Smart Monitoring System Using ESP8266 Node MCU Module," International Journal Of Scientific \& Engineering Research, vol. 9 (6), pp. 801-807, 2018

23. D. Ananth, G. Rao, C. Satish, J. Shyam, K. Santosh, U. Prasad and K. Ramya, "Smart Electricity Billing Using Node-MCU," IJSRSET, vol. 6, no. 2, pp. 287-292, 2019.

24. M. Shahadat, A. Mallik and M. Islam, "Development Of An Automated Gas-Leakage Monitoring System With Feedback And Feedforward Control By Utilizing IoT," FACTA UNIVERSITATIS, Series: Electronics and Energetics, vol. 32, no. 4, pp. 615-631, 2019.

25. K. Sankar, J. Rao, B. Ravi, B. Alekhya, P. Sampathkumar, D. K. Ganesh and R. E., " Wireless Health Monitoring System using IOT," IJSRSET, , vol. 6(2), pp. 268-273, 2019.

26. Aosong, "Temperature and humidity module AM2302 Product Manual," www.aosong.com.

27. Kalra, Vandana \& Baweja, Chaitanya \& Simarpreet, Dr \& Chopra, Supriya. (2016). Influence of Temperature and Humidity on the Output Resistance Ratio of the MQ-135 Sensor. International Journal of Computer Science and Software Engineering. 6. 2277.

28. Vui Hin, Tsen \& Ramli, N.I. (2017). Design and Development of a Salbutamol Intake Detector for Low Respiratory Treatment. IOP Conference Series: Materials Science and Engineering. 226. 012142. 10.1088/1757-899X/226/1/012142.

29. Murie Dwiyaniti, Kendi Moro Nitisasmita, Tohazen,"

30. B. Oyebola, "Human Body Motion Triggered Lamp Indicator as an Alert with PIR Sensor for the Hearing Impaired.," International Journal of Engineering Research \& Technology, vol. 4(6), pp. 52-56, 2015.
31. K. Rao, P. Rao and B. Ravi, "PIR Sensor Based Robot with HMH Applications," International Journal of Engineering Research and Development, vol. 12, no. 5, pp. 23-28, May 2016.

32. A. Vijayavargiya, A. Sharma, P. Kumar, M. Yadav, O. Yadav and P. Choudhary, "PIR Motion Sensor for Home Appliance," International Journal of Engineering and Management Research, vol. 6 , no. 2, pp. 48-51, 2016

33. O. Olalekan, " Development of a Sim8001 Based Reprogrammable Household Smart Security System with Recipient Phone Call Alert," International Journal of Computer Engineering In Research Trends, vol. 4, no. 1, pp. 15-20, 2017.

34. K. Iyapo, O. Fasunla, S. Egbuwalo, A. Akinbobola and O. T. Oni., " Design and Implementation of Motion Detection Alarm and Security System," International Journal of Applied Research, vol. 5(1), pp. 33-42, 2017.

35. James M. Fiore, "Embedded Controllers Using C and Arduino" , Version 2.1.4, 18 April 2020

36. Al-Mahturi, Ayad \& Rahim, Ruzairi. (2016)." ULTRASONIC SENSOR FOR DISTANCE MEASUREMENT".

37. CH. Neeraja Soni1 , CH.Sarita2 , Shrikant Maheshwari3 , Basant kumar Sahu4 , Bhavishya Jain5 , Garima Shrivastav,"Distance Measurement using Ultrasonic Sensor and Arduino ",2016

38. Hailu Dibaba "IoT Implementation with Cayenne Platform",2018

39. Dimitrios Serpanos, Marilyn Wolf,'Internet of systems",2018

40. D.W. Johnson and L.H. Townsend,"Controlling Insects in Stored Grain”,ENTFACT-145

41. G, Kavya., Manjushree S, Ranjitha V, Mamatha E, "Vehicle Information Retrieval by Number Plate Detection". International Journal of Advanced Trends in Computer Science and Engineering. 9. 1964-1967. 10.30534/ijatcse/2020/163922020.

42. Alvin Sarraga Alon1 , Jesusimo L. Dioses, Jr. 2," Machine Vision Recognition System for Iceberg Lettuce Health Condition on Raspberry Pi 4b: A Mobile Net SSD v2 Inference Approach", vol 8, number 4, April-2020(IJETER)

https://doi.org/10.30534/ijeter/2020/20842020 